\title{
Regulatory and Licensing Strategy for Microreactor Technology
}

Denise Owusu, Mark R Holbrook, Piyush Sabharwall

August 2018

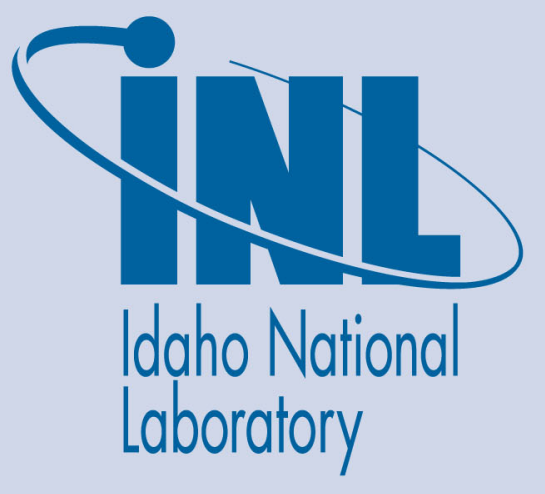

The INL is a U.S. Department of Energy National Laboratory operated by Battelle Energy Alliance 


\title{
Regulatory and Licensing Strategy for Microreactor Technology
}

\author{
Denise Owusu, Mark R Holbrook, Piyush Sabharwall
}

\author{
August 2018
}

Idaho National Laboratory Idaho Falls, Idaho 83415

http://www.inl.gov

Prepared for the U.S. Department of Energy Office of Nuclear Energy Under DOE Idaho Operations Office

Contract DE-AC07-05ID14517 


\section{Regulatory and Licensing Strategy for Microreactor Technology}

\section{INL Summer 2018 Report}

Denise Owusu Carnegie Mellon University

Mark R. Holbrook, Piyush Sabharwall, and Shannon Bragg-Sitton Idaho National Laboratory

August 2018

The INL is a U.S. Department of Energy National Laboratory operated by Battelle Energy Alliance 


\section{DISCLAIMER}

This information was prepared as an account of work sponsored by an agency of the U.S. Government. Neither the U.S. Government nor any agency thereof, nor any of their employees, makes any warranty, expressed or implied, or assumes any legal liability or responsibility for the accuracy, completeness, or usefulness, of any information, apparatus, product, or process disclosed, or represents that its use would not infringe privately owned rights. References herein to any specific commercial product, process, or service by trade name, trade mark, manufacturer, or otherwise, does not necessarily constitute or imply its endorsement, recommendation, or favoring by the U.S. Government or any agency thereof. The views and opinions of authors expressed herein do not necessarily state or reflect those of the U.S. Government or any agency thereof. 


\title{
Regulatory and Licensing Strategy for Microreactor Technology
}

\author{
INL Summer 2018 Report \\ Denise Owusu \\ Mark R. Holbrook \\ Piyush Sabharwall \\ Shannon Bragg-Sitton
}

August 2018

\section{Idaho National Laboratory Originating Organization [optional] Idaho Falls, Idaho 83415}

http://www.inl.gov

Prepared for the

U.S. Department of Energy

Office of Nuclear Energy

Under DOE Idaho Operations Office

Contract DE-AC07-05ID14517 




\section{EXECUTIVE SUMMARY}

Microreactors, often referred to as special-purpose reactors or vSMRs, are neutronically simple, factory manufacturable, easily transportable, and designed to produce up to $20 \mathrm{MW}$ thermal energy (MWt). This power limit allows micro reactors to be classified as Hazard Category 2 per 10 CFR 830, DOE-STD-1027. These reactors are decentralized energy sources that have the ability to provide sustainable and affordable heat and power to remote communities and to industrial users, while having self-contained geometry that requires very low maintenance.

In order for microreactors to be approved for operation, they must abide by and successfully complete a rigorous regulatory and licensing process through the Nuclear Regulatory Commission (NRC), the Department of Energy (DOE), or the Department of Defense (DoD). Since microreactors are a relatively new and disruptive technology that could be used for commercial or military applications, there is no clearly designated licensing path for them to follow. Current licensing frameworks are tailored specifically to large, traditional light water reactors (LWRs) that have been developed and understood by the nuclear industry for many years. Microreactors have significant design differences relative to the more commonly used LWRs, specifically with regard to materials, coolant, reflectors and potential applications. Because they are much more compact, emergency planning zones (EPZs), the amount of space required for assembly, and the distances required to meet dose-based regulatory criteria can technically be altered to better fit their new size.

The following strategies and recommendations associated with each potential licensing or permitting body are intended to assure that key licensing issues do not influence the path to microreactor development, demonstration, and commercialization:

\section{Nuclear Regulatory Commission}

- The NRC should address the lack of definitive data and support of risk informed decision-making concepts from staff members and continue to advance and communicate risk initiatives using their Risk Informed Steering Committee

- More research should be conducted with regard to whether or not microreactors, which are small Class 103 facilities, can be licensed using Class 104-type guidance (e.g., NUREG 1537)

- $\quad$ The NRC should use frequency-consequence curves to incrementally reduce regulatory uncertainty and risk to facilitate future construction and operation of advanced reactor designs 


\section{Department of Energy}

- The DOE should continue to implement their multi-step Phenomena Identification and Ranking Table process in order to help detect and recommend the major design and technology work needed for licensing future reactor systems

- The DOE should consider a joint licensing approach with the NRC where microreactors first go through the DOE process to allow early demonstration on a DOE site, then finish with the NRC process, providing an advantage for both applicants and NRC staff

\section{DOE Process $\quad$ NRC Process}

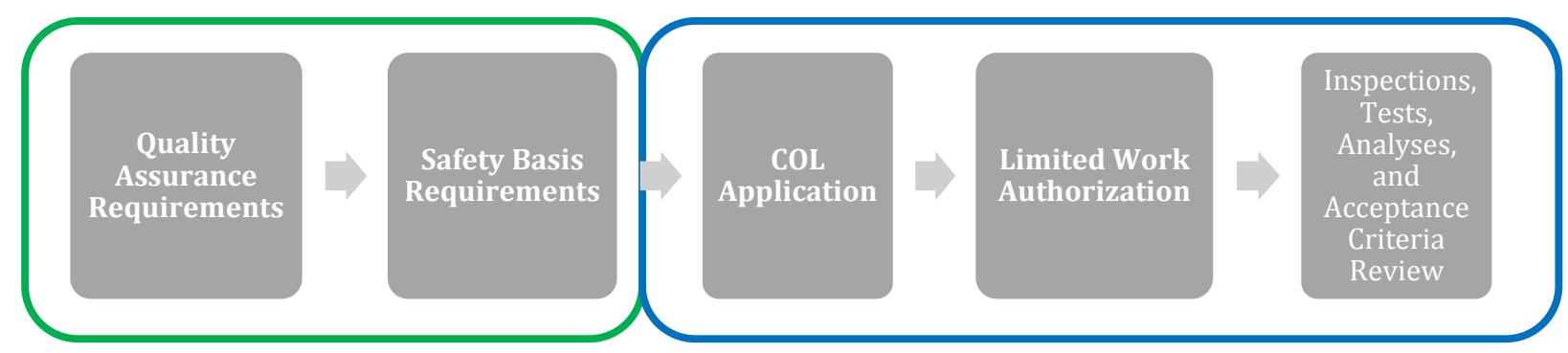

Department of Defense

- The DoD should incorporate microreactors into tactical power systems and hire personnel with expertise (in supporting semi-autonomous operation of microreactors) to self-regulate using Section $91 \mathrm{~b}$ of the Atomic Energy Act

Transportation

- $\quad$ The DOE should provide support in developing new shipping packages for safe transport, criticality benchmark data needed to license high-assay low-enriched uranium fuel facilities and transport packages, and provide financial and technical assistance to the Department of Transportation

- $\quad$ The NRC should aid transportation efforts by finalizing and developing guidance for implementing 10 CFR 73 and 10 CFR 74 specifically for Category 2 Special Nuclear Material 


\section{ACKNOWLEDGMENTS}

I would like to thank The National GEM Consortium for providing me with a fellowship, Carnegie Mellon University for continued support of my graduate education, and Idaho National Laboratory for hosting and providing me with mentorship this summer. Special thanks to my mentors Mark R. Holbrook, Dr. Piyush Sabharwall and Dr. Shannon Bragg-Sitton for their contributions and support of this work. 


\section{CONTENTS}

EXECUTIVE SUMMARY iv

ACRONYMS

$\mathrm{X}$

1. INTRODUCTION

Error! Bookmark not defined.

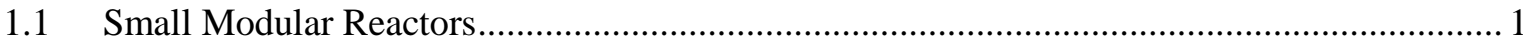

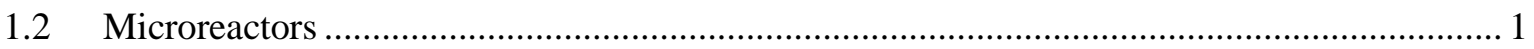

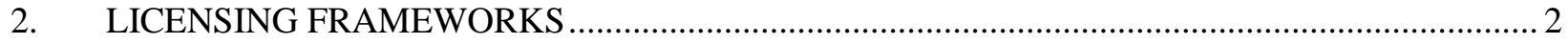

2.1 Introduction to Regulation and Licensing Challenges ........................................................ 2

2.2 Nuclear Regulatory Commission Strategy …..................................................................... 3

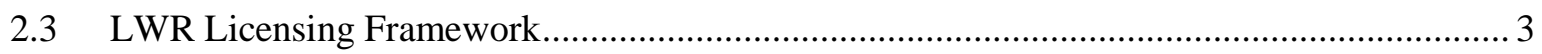

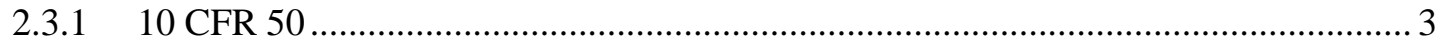

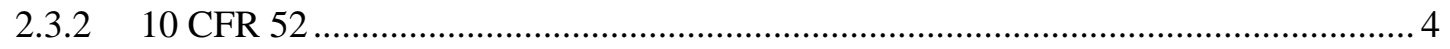

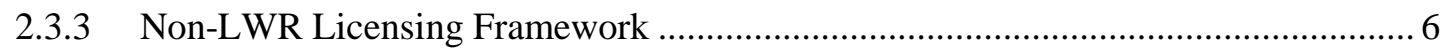

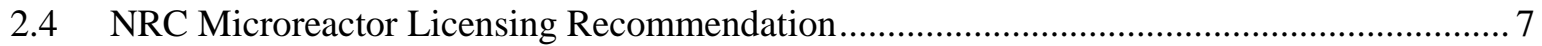

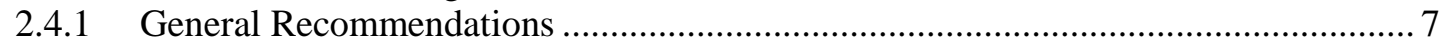

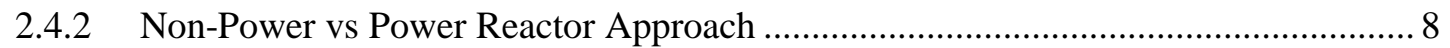

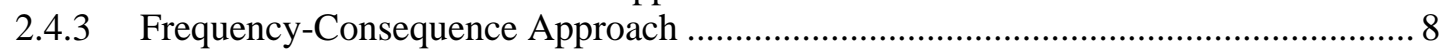

$2.5 \quad$ Department of Energy (DOE) Strategy ....................................................................... 9

2.5.1 Subpart A-Quality Assurance Requirements........................................................ 9

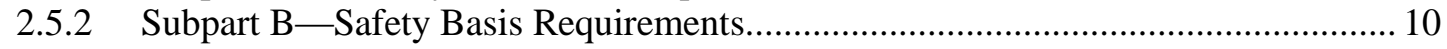

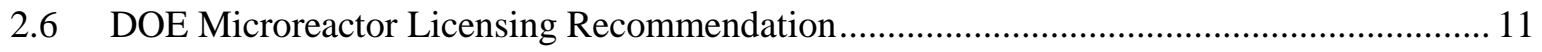

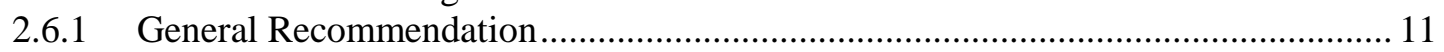

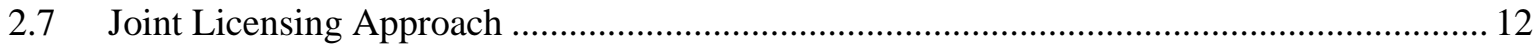

2.8 Department of Defense (DoD) Strategy ...................................................................... 13

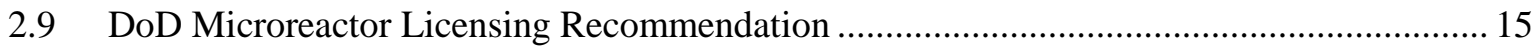

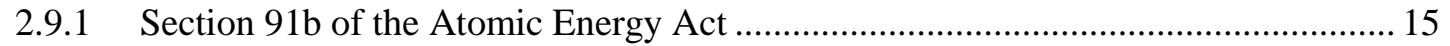

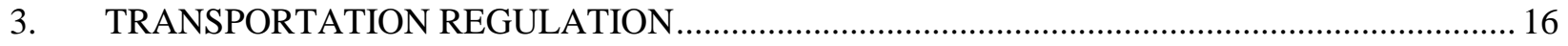

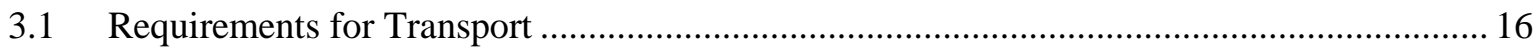

3.1.1 International Atomic Energy Agency Regulations .............................................. 16

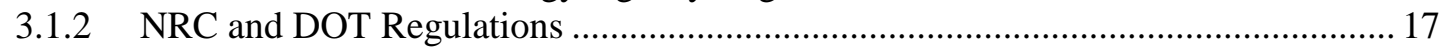

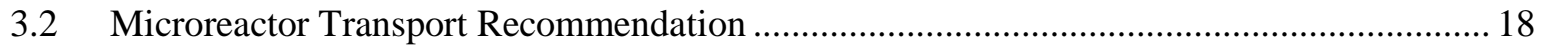

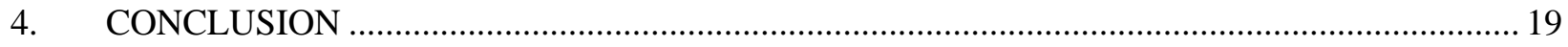

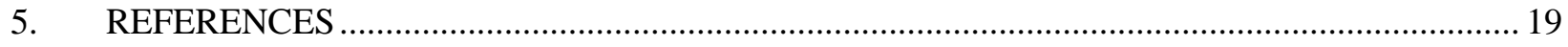

FIGURES

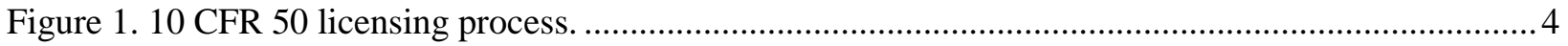

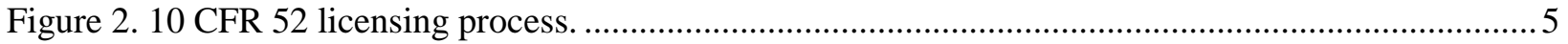




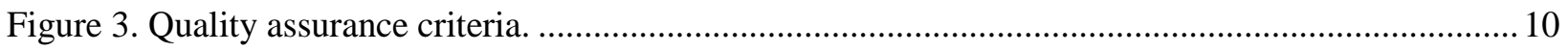

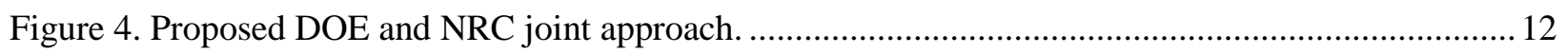

Figure 5. Details associated with Army reactor permit types............................................................... 15

Figure 6. DOD task force vSMR transport to forward or remote operating bases................................... 19

\section{TABLES}

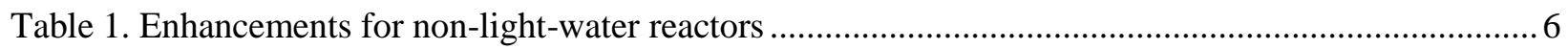

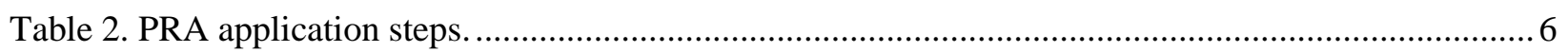

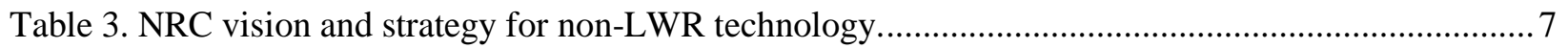

Table 4. Event categories examined for frequency-consequence curves............................................... 9

Table 5. Key points of proposed memorandum of understanding. ......................................................... 13

Table 6. Suggested characteristics of advanced vSMRs......................................................................... 14

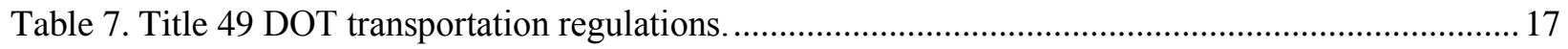




\section{ACRONYMS}

ADAMS Agency-wide Documents Access and Management System

AR Army Regulation

ARO Army Reactor Office

CFR Code of Federal Regulations

COL construction and operating licensing

$\mathrm{CP} \quad$ construction permit

DC design certification

DoD Department of Defense

DOE Department of Energy

DOT Department of Transportation

EIA Energy Information Administration

EPZ Emergency Planning Zone

ESP early site permit

FC frequency-consequence

HALEU high-assay low-enriched uranium

IAEA International Atomic Energy Agency

IAP implementation action plan

ITAAC inspections, tests, analyses, and acceptance criteria

LEU low-enriched uranium

LWR light water reactor

NRC Nuclear Regulatory Commission

NREG US Nuclear Regulatory Commission Regulation (a document type)

OL operating license

PIRT Phenomena Identification and Ranking Table

PRA probabilistic risk assessment

QA quality assurance

QAP Quality Assurance Program

RIDM risk-informed decision making

RISC Risk Informed Steering Committee

SMR small modular reactor

TEDE total effective dose equivalent

USQ unreviewed safety question

vSMR very small modular reactor (microreactor) 


\section{Regulatory and Licensing Strategy for Microreactor Technology}

\section{INTRODUCTION}

Nuclear energy is a reliable, dispatchable energy generation source that does not emit air pollution or greenhouse gases. It also decreases the country's reliance on fossil fuels, which can have unpredictable pricing fluctuations due to political turmoil like the oil embargo of the 1970s. As of 2017, fossil fuels contributed to $62.7 \%$ of U.S. electricity generation, while nuclear only contributed roughly $20 \% .{ }^{[1]}$ With stable, reliable and dispatchable nuclear energy, the United States can begin to lower its dependence on fossil fuels and avoid the negative effects of volatile prices and carbon emissions. ${ }^{[4]}$

\subsection{Small Modular Reactors}

Advanced reactor systems are designed to address the future sustainability of nuclear energy, increase competitiveness in the market place, and enhance the safety, reliability, and proliferation resistance. Examples of these advanced systems include very-high-temperature gas-cooled reactors, gas-cooled fast reactors, sodium-cooled fast reactors, lead-cooled fast reactors, molten-salt reactors, supercritical watercooled reactors, and heat pipe reactors. ${ }^{[5]}$

Small modular reactors (SMRs) are rated to operate at a maximum of $300 \mathrm{MWe}$, have inherent passive safety features and are modularly constructed. Their small size enables them to be economical in areas with smaller energy needs, and usable in isolated locations that have high electricity prices or no access to advanced infrastructure. Their size also allows more site construction flexibility because additional reactor units can be incorporated into the design as needed and can be clustered to create a multi-module, largecapacity power plant. SMRs require smaller initial capital investments, reduce financial risks, and have lower operation and maintenance costs relative to traditional large-scale nuclear plants. ${ }^{[6]}$ Because they can be mass produced in a factory, construction time is significantly shortened - to about three versus six years - which reduces scheduling risks and project timelines. ${ }^{[7]}$ With shorter project timelines, the longterm financial debt costs are decreased as well. ${ }^{[8]}$

SMRs enhance safety for both the plant and the public by eliminating most accident initiators through improved decay-heat removal, which requires less human intervention. ${ }^{[6]}$ Developers plan to enhance seismic safety by using seismic isolation systems and by having reactor vessels that are built within embedded systems to protect them from additional seismic and external hazards. ${ }^{[8]}$ In comparison to larger nuclear plants, SMRs are expected to be more competitive in the market place because they can provide nearly continuous power when there are multiple units on a site (e.g. only a small percentage of the plant would be offline at any given time for refueling) and through their capability to (1) replace coal fired plants, (2) provide combined electricity and process heat for industrial applications, and (3) support intermittent renewable energies. ${ }^{[8]}$

\subsection{Microreactors}

Similar to SMRs, microreactors are designed to be neutronically simple, factory manufacturable, and easily transportable. These systems would nominally generate energy on the megawatt scale, up to approximately $20 \mathrm{MWt}$ for classification as Hazard Category 2, per 10 Code of Federal Regulations [CFR] 830, DOE-STD-1027. ${ }^{[9]}$ Also referred to a special-purpose reactors or very small modular reactors 
(vSMRs), these reactors are decentralized energy sources that have the ability to provide sustainable and affordable heat and power to remote communities and to industrial users. ${ }^{[10][11]}$

Microreactors can be used commercially to meet remote energy needs, or for defense applications to provide uninterrupted mobile power for military installations without the threat of cyber vulnerabilities. ${ }^{[9]}$ For example, remote Arctic communities that are far from the main grid and currently rely on diesel generators can benefit from the convenience and reliability of microreactor use, instead of inefficiently hauling in diesel fuel supplies to their site via truck, waterway, or plane. ${ }^{[10]}$

Microreactor customers can also benefit from: (1) energy independence, as these systems provide a more sustainable alternative to imported fuel, (2) a low environmental impact, as the reactor has a small footprint, is completely contained and has zero carbon emissions, (3) scalable power that can be tailored to fit a community's energy needs, and (4) affordable energy that enables economic development. These reactors are inherently safe because they are self-regulating and do not rely on physical systems to ensure safe shut down and removal of decay heat. In comparison to other energy technologies, such as solar and wind power, microreactors can provide reliable baseload energy within a small footprint, only requiring on the order of 0.06 acres versus 48-79 acres used for comparable solar power generating capacity and 275380 acres for wind. ${ }^{[10]}$

\section{LICENSING FRAMEWORKS}

In order for microreactors to be approved for operation, they must abide by and successfully complete a rigorous regulatory and licensing process through the NRC, DOE or DoD. The licensing framework for each of these federal agencies is described below.

\subsection{Introduction to Regulation and Licensing Challenges}

The NRC, which has about 3,300 employees and is led by a five member commission, regulates the use of nuclear materials in order to protect public health and safety by establishing standards, issuing licenses, inspecting facilities, and setting limits on radiation exposure. ${ }^{[12]}$ With respect to nuclear, the DOE is responsible for the research, development, and promotion of nuclear power in order to ensure America's security and prosperity. ${ }^{[13][14]}$ Production, test, and research reactors can be found on DOE owned and operated sites; many of these facilities are used to demonstrate the suitability of commercial applications. ${ }^{[15]}$ The DoD's mission is to provide the military forces needed to deter war and to protect the security of the country. ${ }^{[16]}$ When it comes to reactor technology, a DoD task force has found that using microreactors on forward operating and remote operating bases could be very useful, providing "reliable, abundant, and continuous energy for current and anticipated future military energy requirements and demands". ${ }^{[17]}$ The NRC, DOE and DoD are also responsible for the design, construction, operation, maintenance, decommissioning, and decontamination of nuclear infrastructures and for insuring that processes and materials meet expected levels of performance and safety. Using quality assurance (QA) programs enables these organizations to provide quality control and oversight of nuclear facilities through the use of audits, inspections, testing and corrective action reports. ${ }^{[18]}$

Since microreactors are a relatively new and disruptive technology, there is no clearly defined licensing path to follow. Current licensing frameworks are tailored specifically to traditional large LWRs that have been developed and understood by the nuclear industry for many years. Microreactors have significant design differences relative to the more commonly used LWRs, specifically with regard to materials, coolant, reflectors and potential applications. Because they are much more compact, emergency planning zones (EPZs), the amount of space required for assembly, and the distances required to meet dose-based regulatory criteria can technically be altered to better fit their new size. ${ }^{[7][19]}$ As is true of SMRs, the most important aspects to be considered when assessing microreactors for operation are reactor safety, radiation 
protection, and power plant security. ${ }^{[6]}$ More specifically, when applying for a license, applicants must address reactor containment, coolant boundaries, fission products, and fuel performance. Vendors and utilities must also analyze possible plant events, such as the impact of an earthquake, that may challenge the reactor integrity. Applicants must also consider human factors, environmental issues, probabilistic risk assessment (PRA), and source terms. The following strategies and recommendations are intended to ensure that key licensing issues do not impact the path to microreactor development, demonstration, and commercialization. ${ }^{[19]}$

\subsection{NRC Licensing Frameworks}

The Atomic Energy Act of 1954 requires every nuclear power plant (or other facility handling radioactive materials) to be licensed by the federal government for construction and operation. This means that all commercial nuclear plants that provide electricity to the grid must first obtain a license from the NRC. ${ }^{[20][21]}$ The NRC has licensed all 99 of the currently operating nuclear power reactors in the United States. These licenses include critical information such as (1) type and amount of radioactive material that may be held or used, (2) training and qualifications of workers, (3) specific procedures for using the materials, and (4) special safety precautions. ${ }^{[12]}$ According to the NRC, their established safety goals are to:

provide individual members of the public with a level of protection from the consequences of nuclear power plant operation such that individuals bear no significant additional risk to life and health,

and to ensure that:

societal risks to life and health from plant operation are comparable to or less than the risks of generating electricity by viable competing technologies. ${ }^{[22]}$

\subsection{LWR Licensing Framework}

As previously stated, licensing frameworks for LWRs have been developed and understood by the nuclear industry for many years. The 2 main frameworks are 10 CFR 50 and the 10 CFR 52, which were created to provide steps for licensing a LWR through the NRC.

\subsubsection{CFR 50}

The first nuclear plant licensing process was designed for LWRs and is described in "Domestic Licensing Production and Utilization Facilities" found in 10 CFR 50. This process, outlined in Figure 1, consists of a two-part licensing process with two opportunities for public intervention. In Part 1, applicants must apply for and obtain a construction permit (CP) in order to begin building the facility. Before the applicant can begin construction, the first set of public hearings are scheduled near the proposed site to discuss safety and environmental aspects of application, planned location, and NRC's licensing process. ${ }^{[21]}$ After these initial public hearings and NRC review of the preliminary design, applicants may be issued a permit to begin construction.

During construction, applicants proceed to Part 2, where they must apply for and obtain an operating license (OL). Once they have applied, a final mandatory hearing is conducted; if all safety and environmental requirements are met, the NRC then issues the operating license, enabling the applicant to load fuel and begin operating the plant. ${ }^{[21]}$ 


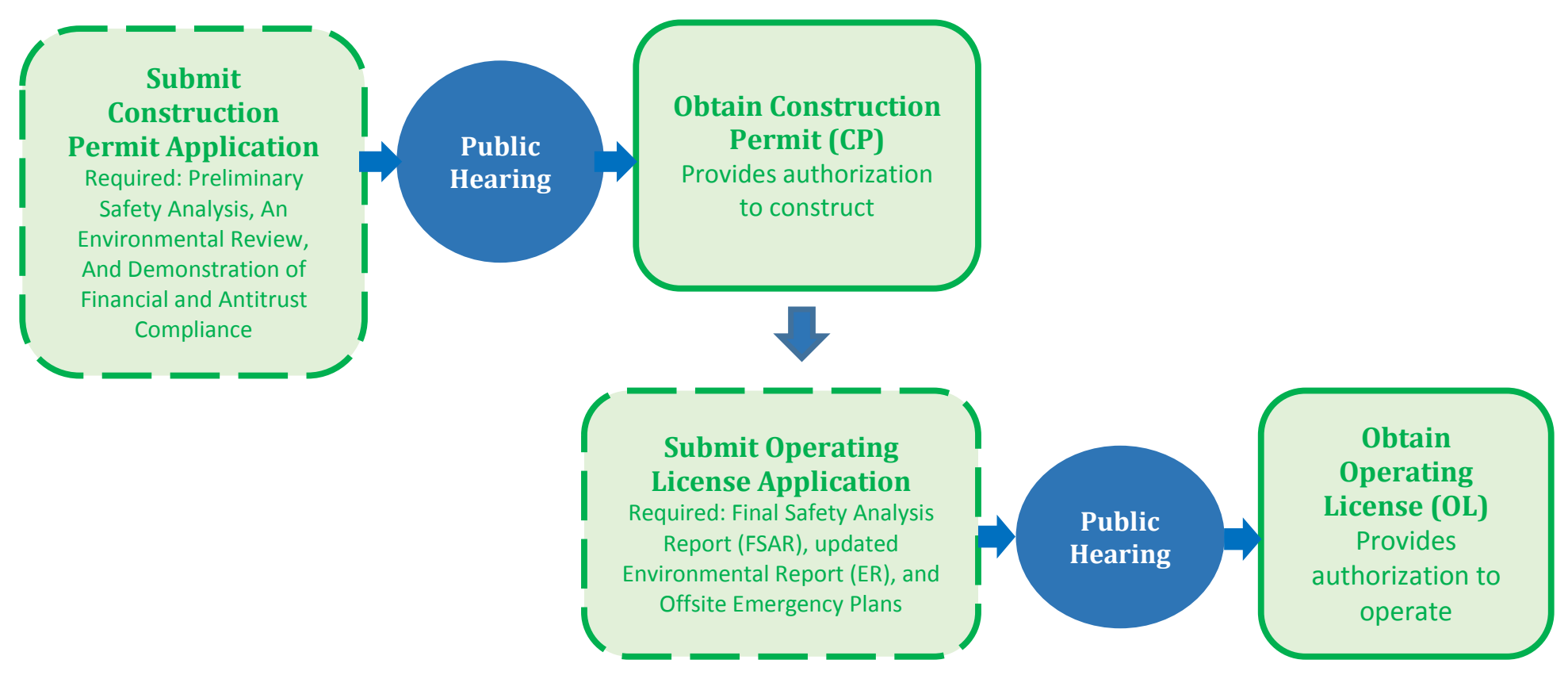

Figure 1. 10 CFR 50 licensing process.

Two main issues arise while engaging in this process. The first issue is that applicants begin construction with only preliminary (instead of final) plant designs that they then inspect as they go along, ultimately resulting in a large amount of reworking of the design due to a potential lack of compliance with regulations that is only determined during the construction process. This not only takes more time, but consequently raises costs as well. In one case, a reactor that was estimated to cost $\sim \$ 500$ million and taken six years to build took several billion dollars and more than ten years to complete. ${ }^{[12]}$ The second issue is the length of time of the hearings conducted prior to the issuing of the OL. As the industry matured, and in light of incidents like Three Mile Island, hearings could take as long 23 years to complete. This leaves completed plants idle while facing economic pressures from construction costs. In some cases, applicants have abandoned the application completely due to the foreseen financial strain. ${ }^{[20]}$

\subsection{2 $\quad 10$ CFR 52}

In order for the construction of nuclear facilities to be financially viable, major changes had to be made to reduce the economic and regulatory risk associated with the licensing process. In April 1989, the NRC created an alternative process based on new regulations designated in 10 CFR 52. This process combines the CP and OL application steps (Parts 1 and 2 of 10 CFR 50) to streamline the licensing process and ensure a more predictable regulatory environment for new reactor licensing. ${ }^{[20]}$ It shortens the licensing and construction period to between nine and ten years, instead of up to 23 years, allows for early resolution of safety and environmental issues, and removes regulatory barriers before applicants invest in resources for the project, thereby reducing project risk. ${ }^{[20][21]}$ 


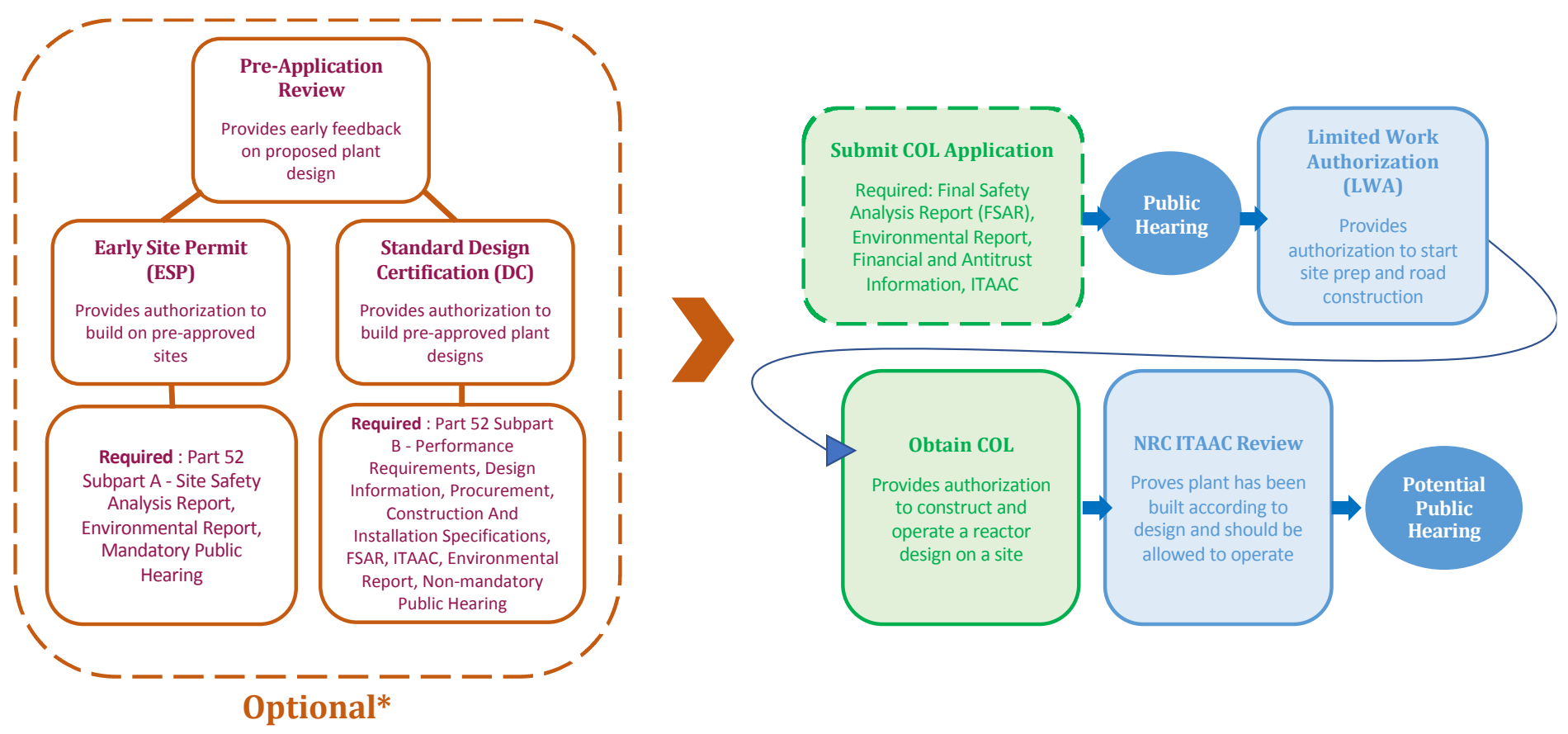

Figure 2. 10 CFR 52 licensing process.

The combined construction and operating licensing (COL) process allows the applicant to partake in an optional pre-application review and attain both an early site permit (ESP) and a design certification (DC) prior to applying for the COL. The pre-application review is performed by the NRC and allows applicants to get early feedback on any licensing issues they may face with their proposed design. The ESP is valid for 20 years and gives the applicant the ability to build on pre-approved reactor sites. ${ }^{[20]}$ This permit addresses plans for coping with emergencies, site safety, and environmental protection issues. ${ }^{[21]}$ The DC is valid for 15 years and gives the applicant the ability to certify pre-approved plant designs. If the applicant chooses not to seek an ESP and/or DC prior to the COL, the applicant still must provide complete design and site information that would have been present in the ESP and DC as part of the COL application. Once an applicant has obtained both the permit and certification information, they can begin to file an application for the COL, which authorizes construction and conditional operation of a specific reactor design on a specific site. The license is valid for up to 40 years and takes the NRC about 42 months to approve. ${ }^{[3]}$ After the application is submitted, it is reviewed by the Advisory Committee on Reactor Safeguards and the NRC, then debated at a public hearing. Prior to receiving COL approval from the NRC, applicants have the opportunity to save about 18 months on their construction schedules by requesting an optional limited work authorization, which allows the applicant "to perform the driving of piles, subsurface preparation, placement of backfill, concrete or permanent retaining walls within an excavation, and installation of the foundation". ${ }^{[21]}$ After the NRC has issued the COL and the applicant has constructed the plant, the NRC verifies that the required inspections, tests, analyses, and acceptance criteria (ITAAC) have been met to prove that the plant has been built according to design and should be allowed to operate. ${ }^{[3]}$ Members of the public then have the option to participate in an additional hearing, which is then followed by approval to operate the plant. The entire process is outlined in Figure 2.

The 10 CFR 52 process saves both time and money by requiring that applicants' final designs be completed prior to granting of the COL. This prevents the design-as-you-build approach and allows for immediate operation of the plant once construction and testing are complete, as long as design specifications are met. ${ }^{[3]}$ There is also less delay because all intervening opportunities by the public must be backed by evidence that an ITAAC has not or will not be met. 


\subsubsection{Non-LWR Licensing Framework}

In the 1980s, the NRC began creating strategies for licensing the next generation of reactors. They did this by developing guidance for a flexible regulatory review process within the bounds of existing regulation, using years of experience from operating reactors and insights gained through detailed assessments. ${ }^{[22][23]}$ These next generation reactors include non-LWR (or Generation IV) designs that use non-water coolants such as molten salt, liquid metal, and helium to cool the reactor core ${ }^{[23]}$ Expectations for these new designs include: (1) simplified safety systems that require fewer operator actions, (2) reliable equipment that reduces the need to activate safety systems, and (3) easily maintainable equipment that reduces plant personnel radiation exposure during maintenance activities. To accomplish this the Commission used a series of policy papers stating enhancements to be imposed on newly proposed reactor designs. These proposed enhancements are summarized in Table 1. ${ }^{[22]}$

Table 1. Design enhancements for non-light-water reactors.

- A diverse shutdown system to ensure shutdown of the reactor even if the main system fails

- Design features to ensure high reliability of the shutdown decay heat removal system

- An alternate AC power source to mitigate station blackout (optional)

- Safe shutdown without operator intervention, even if a fire disables all equipment in one fire area

- Methods to maintain core cooling and to minimize spread of core in the event of a severe accident

- A depressurization system and reactor cavity design features to contain ejected core debris in the event of a severe accident

Previous licensing requirements consisted of conservative, deterministic criteria that were heavily based on qualitative risk assessments and engineering judgement. ${ }^{[24]}$ The NRC has since refined their deterministic-based regulations by incorporating risk information and insights through probabilistic risk assessments (PRAs) ${ }^{[25]}$ PRAs are used to estimate risk by computing real numbers to predict what could go wrong, the likelihood of occurrence, and the severity of the consequences. ${ }^{[2]}$ PRAs are used during the design and licensing process and are capable of enhancing both safety and operational flexibility. PRAs also ensure that "significant insights are not obscured by artificially biased results derived from the application of uneven conservatisms" found in deterministic-based regulations. ${ }^{[25]}$ The 10-step application process for a PRA is provided in Table 2.

Table 2. PRA application steps.

\begin{tabular}{|l|l|}
\hline Stage A & $\begin{array}{l}\text { 1. Characterize plant design life cycle stage and PRA application. } \\
\text { 2. Characterize site characteristics. } \\
\text { 3. Select PRA scope and level of detail consistent with design stage and applications. } \\
\text { 4. Determine capability category needed for each portion of the PRA. }\end{array}$ \\
\hline Stage B & 5. Verify PRA scope and risk metrics are sufficient to support application. \\
\hline Stage C & 6. Determine requirements in the PRA Standard are sufficient for application. \\
\hline Stage D & 7. Determine that PRA satisfies requirements for application. \\
\hline Stage E & $\begin{array}{l}\text { 8. Ensure that PRA has sufficient capability. } \\
\text { 9. Use PRA to support the application. } \\
\text { 10. Provide risk input to decision maker. }\end{array}$ \\
\hline
\end{tabular}

In addition to PRAs, the NRC established steps towards minimizing risks through the preparation of the NRC Vision and Strategy: Safely Achieving Effective and Efficient Non-Light Water Reactor Mission Readiness document (No. ML16356A670) found in the Agency-wide Documents Access and Management 
System (ADAMS). This strategy document was created to improve the NRC's readiness to regulate nonLWR technologies. The document includes implementation action plans (IAPs) that develop technical readiness, regulatory readiness and communications. According to the NRC:

Regulatory readiness includes the clear identification of NRC requirements and the effective and timely communication of those requirements to potential applicants in a manner that can be understood by stakeholders with a range of regulatory maturity. ${ }^{[23]}$

Table 3 summarizes the contributing activities for improving the regulatory readiness for non-LWR designs.

Table 3. NRC vision and strategy for non-LWR technology.

\begin{tabular}{|l|}
\hline \multicolumn{1}{|c|}{ Activities for Improving Readiness } \\
\hline $\begin{array}{l}\text { Establish and document the criteria necessary to reach a safety, security, or } \\
\text { environmental finding for non-LWR applicant submissions }\end{array}$ \\
\hline $\begin{array}{l}\text { Determine and document appropriate non-LWR licensing bases and accident } \\
\text { sets for highly prioritized non-LWR technologies }\end{array}$ \\
\hline $\begin{array}{l}\text { Identify, document, and resolve (or develop a plan to resolve) current } \\
\text { regulatory-framework gaps for non-LWRs }\end{array}$ \\
\hline $\begin{array}{l}\text { Develop and document a regulatory review "roadmap" that reflects the design } \\
\text { development lifecycle and appropriate points of interaction with the NRC and } \\
\text { references appropriate guidance to staff reviewers and applicants }\end{array}$ \\
\hline $\begin{array}{l}\text { Prepare and document updated guidance for prototype testing, research and test } \\
\text { reactors }\end{array}$ \\
\hline $\begin{array}{l}\text { Engage reactor designers and other stakeholders regarding technology- and } \\
\text { design-specific regulatory engagement plans and develop regulatory approaches } \\
\text { commensurate with the risks posed by the technology }\end{array}$ \\
\hline $\begin{array}{l}\text { Support longer-term efforts to develop, as needed, a new non-LWR regulatory } \\
\text { framework that is risk-informed, performance-based, and that features staff } \\
\text { review efforts commensurate with the demonstrated safety performance of the } \\
\text { non-LWR nuclear power plant design being considered }\end{array}$ \\
\hline
\end{tabular}

\subsection{NRC Microreactor Licensing Recommendation}

\subsubsection{General Recommendations}

As previously mentioned, the integration of risk-informed performance-based regulatory frameworks into regulatory decision-making practices has the ability to provide licensees of advanced non-LWR technologies many great benefits, such as increasing efficiency and consistency and improving the technical basis for regulatory activities, all while ensuring protection of public health and safety. For microreactors to benefit from risk-informed decision making (RIDM), the NRC must continue to address the issues faced by licensees in the past.

The first issue is the lack of definitive data and support of RIDM concepts from NRC staff members. A majority of NRC staff members were not required to complete training on the regulatory aspects and quantitative risk techniques of RIDM, which makes it difficult to apply RIDM concepts consistently and efficiently. To solve this, the NRC must continue to enhance mandatory training requirements for both managers and staff, and to evaluate and update RIDM guidance techniques to create a collaborative review process. The NRC must also continue to spread the knowledge and the importance of RIDM in order to attain successful execution. ${ }^{[26]}$ 
The second issue is that many licensees create unrealistic PRA modeling assumptions that can mask high-risk contributors due to modeling-capability limitations. To mitigate this challenge, the NRC must continue to advance risk initiatives by using their Risk Informed Steering Committee (RISC). The RISC helps to promote sufficient PRAs by engaging with industry, listening to PRA concerns, discussing initiatives to incentivize the development of PRAs, and discussing actions necessary to achieve the future goals of PRA use. The NRC has also begun to increase communication on risk-informed activities by requiring members with expertise to share knowledge and experience via presentations given at branch and division meetings. Through these actions, individuals from technical branches can learn about risk insights and safety significance in a tailored and informative manner. ${ }^{[26]}$

\subsubsection{Non-Power vs Power Reactor Approach}

A power reactor is a reactor that generates electricity. A non-power (or research and test) reactor is a reactor that does not produce electrical power and is often used for research training, materials testing, production of radioisotopes for medicine, or other development purposes. Non-power reactors are generally smaller and simpler relative to power reactors, requiring far less fuel and producing less fission-product buildup, which makes them relatively less risky. ${ }^{[27][28]}$ Non-power reactors are licensed by the NRC consistent with the NRC mission, and are overseen by the NRC's Office of Nuclear Reactor Regulation. The Commission's regulations, found in 10 CFR 55, require that

\section{Personnel who operate a reactor must have either a Reactor Operator or a Senior Operator license issued by the NRC, and must have the required knowledge, skills and abilities to control the reactor during both routine operations and emergencies. $^{[27]}$}

Though similar to power reactors, the licensing process for non-power reactors is much faster due to significant differences in complexity and hazards between the two, including "thermal power levels that are several orders of magnitude lower than current power reactors, and less stringent and prescriptive measures to give equivalent protection" of the health and safety of the public. ${ }^{[29]}$ The process is also faster because licensees can apply for a COL (similar to the 10 CFR 52 process) and then submit only one safety analysis report (instead of two) that is acceptable for both permits, enabling the NRC to publish a joint notice of intent in the Federal Register at the construction-permit stage. This joint application and jointnotice procedure helps to significantly streamline the licensing process for non-power reactors. ${ }^{[29]}$

Because microreactors are similar in size and simplicity to non-power reactors, the nuclear community is currently discussing whether they can adopt some of the regulation practices used for research and test reactors. There is some flexibility when classifying a reactor as Class 103 (commercial and industrial), or Class 104 (medical and/or for research and development). According to Part 1 of US NRC Regulation (NUREG)-1537, a document that states the guidelines for preparing and reviewing applications for the licensing of non-power reactors,

The NRC recognizes that a non-power reactor for commercial purposes could be

licensed as a Class 103 facility, and thus, 10 CFR 50.22 contains criteria for

judging if a non-power reactor is a Class 103 facility. ${ }^{[29]}$

Inversely, more research should be conducted with regard to whether or not microreactors, which are small Class 103 facilities, can be licensed using Class 104-type guidance (e.g., NUREG 1537).

\subsubsection{Frequency-Consequence Approach}

Another approach that may expedite the licensing process is the use of licensing basis event (LBE) frequency-consequence (FC) curves. In 2008, the NRC and the DOE jointly developed a Next Generation Nuclear Plant strategy that included a high-level licensing plan for deploying modular high-temperature gas-cooled reactors using existing LWR regulations as a guide. This plan included safety assessments based 
on a risk-informed spectrum of potential events and their frequencies in challenging reactor safety, and toplevel regulatory criteria that establishes the risk targets for LBEs. Top-level regulatory criteria also provide acceptable public-health and safety limits (in terms of radiological consequences).

FC curves are graphs with an $\mathrm{x}$-axis that represents the mean or expected consequence to the public and a y axis that represents the mean or expected frequency expressed in per plant-year. These curves can be used as an acceptable radiation-dose guide to designers, to select licensing basis events, and as a surrogate risk metric to quantitative health objectives ${ }^{[25]} \mathrm{FC}$ curves are beneficial in the licensing process because they incrementally reduce regulatory uncertainty and risk to facilitate future construction and operation of advanced non-LWR designs. ${ }^{[30]}$ The event categories that are used to establish the curves are split into three frequency ranges: anticipated operational occurrences, design basis events and beyond design basis events. The details of these events are summarized in Table 4.

Table 4. Event categories examined for frequency-consequence curves.

\begin{tabular}{|l|l|l|}
\hline \multicolumn{1}{|c|}{ Event } & \multicolumn{1}{|c|}{ Definition } & \multicolumn{1}{c|}{ Criteria } \\
\hline $\begin{array}{l}\text { Anticipated Operational } \\
\text { Occurrences }\end{array}$ & $\begin{array}{l}\text { Expected to occur one or more } \\
\text { times during the life of the plant }\end{array}$ & $\begin{array}{l}\text { Total effective dose equivalent } \\
\text { (TEDE) for a member of the } \\
\text { public limited to 100 mrem per } \\
\text { year and 2 mrem in any one hour, } \\
\text { in unrestricted areas }\end{array}$ \\
\hline Design Basis Events & $\begin{array}{l}\text { Not expected to occur during the } \\
\text { lifetime of a single nuclear } \\
\text { power plant, but may be } \\
\text { encountered during the lifetime } \\
\text { of a population of nuclear power } \\
\text { plants of similar design }\end{array}$ & $\begin{array}{l}\text { An individual located at any point } \\
\text { on the exclusion area boundary } \\
\text { would not receive a radiation dose } \\
\text { in excess of 25 rem TEDE for any } \\
\text { two-hour period following the } \\
\text { onset of a postulated fission } \\
\text { product release }\end{array}$ \\
\hline $\begin{array}{l}\text { Beyond Design Basis } \\
\text { Events }\end{array}$ & $\begin{array}{l}\text { Improbable events that are not } \\
\text { expected to occur during the } \\
\text { lifetime of a large fleet of } \\
\text { nuclear power plants }\end{array}$ & $\begin{array}{l}\text { Overall risk to the public is } \\
\text { acceptably low; adequate } \\
\text { emergency planning is in place to } \\
\text { address these highly improbable } \\
\text { events }\end{array}$ \\
\hline
\end{tabular}

\subsection{Department of Energy Licensing Strategy}

The DOE's nuclear safety management regulatory information can be found within 10 CFR 830 . The purpose of this section is to "govern the conduct of contractors, DOE personnel, and other persons conducting activities that affect or may affect the safety of DOE nuclear facilities". ${ }^{[1]} 10$ CFR 830 consists of two major requirements: Quality-assurance requirements found in Subpart A, and safety basis requirements found in Subpart B.

\subsubsection{Subpart A-Quality Assurance Requirements}

Subpart A is broken up into two sections, the Quality Assurance Program (QAP) and the quality assurance criteria. All contractors that are responsible for DOE nuclear facilities are required to submit a QAP to the DOE for approval, modify it as directed by DOE, and annually submit any changes made for approval. The QAP must: (1) sufficiently describe how the quality assurance criteria are satisfied, (2) integrate quality assurance criteria with the safety management system, and (3) use and identify voluntary consensus standards in its development. ${ }^{[31]}$ The quality assurance criteria consist of nine criteria that must be addressed: program, personnel training and qualification, quality improvement, documents and records, 
work processes, design, procurement, inspection and acceptance testing, and management and independent assessment. The details of each criterion can be found in Figure 3.
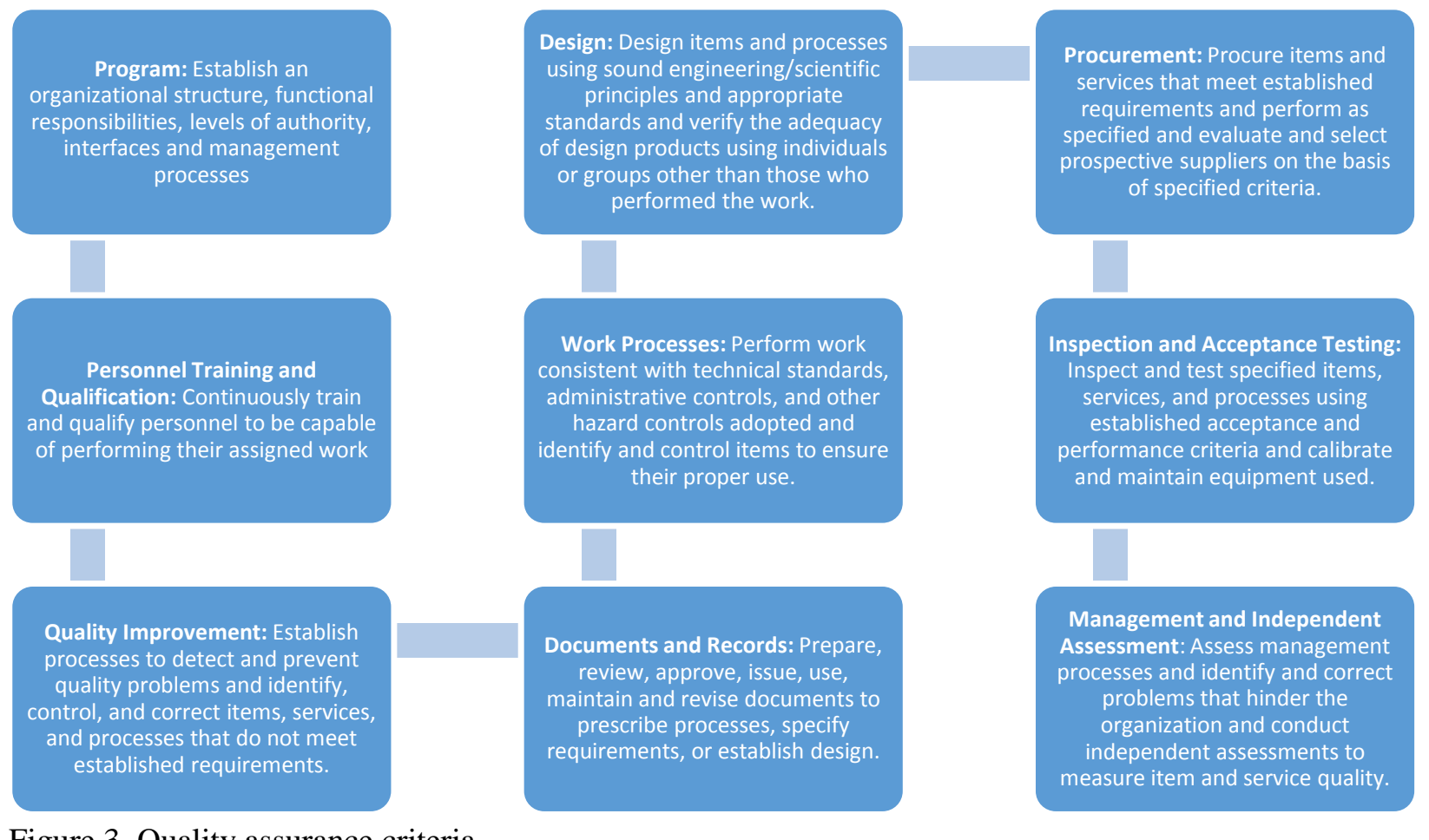

Figure 3. Quality assurance criteria.

\subsubsection{Subpart B-Safety Basis Requirements}

The purpose of Subpart B is to establish the safety basis requirements for Hazard Category 1, 2, and 3 DOE nuclear facilities. This section is broken up into six parts: safety basis, unreviewed safety question (USQ) process, documented safety analysis, technical safety requirements, preliminary documented safety analysis and DOE approval of safety basis.

In establishing the safety basis, a contractor must: (1) define the scope of the work, (2) identify and analyze the hazards associated with the work, (3) categorize the facility consistent with DOE-STD-102792, (4) prepare a documented safety analysis for the facility, and (5) establish hazard controls to ensure adequate protection of workers, the public, and the environment. ${ }^{[31]}$ In the case of microreactors, the designation as nuclear-hazard category of 2 , dictated based on the thermal power level of the reactor, indicates that they "show potential for significant on-site consequences, contain sufficient quantities of hazardous material and energy that would require on-site emergency planning activities, and warrant management attention." ${ }^{[32]}$ The contractor is also responsible for keeping the safety basis up to date and annually submitting any changes to DOE for approval.

During the USQ process, contractors must submit a procedure for the process to DOE for approval. Once approved, the contractor must implement the procedure in situations where there is temporary or permanent change in the facility or procedures, a test or experiment that was not previously described in the existing safety analysis, or a potential inadequacy of the safety analysis. If the contractor discovers a potential inadequacy, they must notify DOE of the situation and take appropriate action to place the facility in a safe condition.

Before preparing a documented safety analysis, the contractor must get the methodology they plan on using for the analysis approved by the DOE. The safety analysis must describe the facility, identify both 
natural and man-made hazards associate with the facility, evaluate accident conditions, and develop the hazard controls necessary to ensure adequate protection.

For the required technical safety requirements, contractors must first obtain DOE approval, then develop requirements that are derived from the documented safety analysis. If the contractor sees fit, they may take emergency actions that differ from an approved technical safety requirement, but only if the actions they use instead are needed to protect workers, the public, or the environment.

Prior to the preliminary documented safety analysis process, contractors must obtain DOE approval of the nuclear safety design criteria to be used in preparing the safety analysis, and then approval for the preliminary safety analysis itself. After this, the contractor must submit a safety basis that meets the requirements of the preliminary document. Once the safety bases meet the requirements, the contractor must notify the DOE, document the adequacy of the existing safety basis and request the DOE to issue a safety evaluation report. A contractor cannot begin operation of the facility prior to the issuance of a safety evaluation report approved by the DOE. ${ }^{[31]}$

\subsection{DOE Microreactor Licensing Recommendation \\ 2.6.1 General Recommendation}

The DOE should continue to implement their multi-step Phenomena Identification and Ranking Table (PIRT) process in order to help detect and recommend the major design and technology work needed for the licensing of future reactor systems. The PIRT process identifies and ranks safety-relevant and safetysignificant phenomena; this ranking is ideal for reactors in the conceptual design phase. The process consists of nine steps. Defining the:

- issue,

- specific objectives,

- hardware and scenario,

- evaluation criteria,

- current knowledge base,

- phenomena identification,

- importance ranking,

- knowledge level, and

- the documentation

The issues to be defined when considering microreactors are the major design changes from traditional reactors designs and the very limited experience that the industry and the DOE have with the technology. The objectives would consist of tasks that include identifying safety-relevant phenomena, establishing evaluation criteria, and assessing material performance requirements to assure safety. The type of information that would need to be included in the hardware and scenario step would include specific details about fuel and heat pipe elements. The evaluation criteria would need to identify the FOM that will be used to judge the relative importance of safety relevant phenomena, such as dose to the public from fission product release. The current knowledge base step would include assessment of the industries' familiarization with microreactor technology.

For phenomena identification, a comprehensive preliminary list of phenomena relevant to safety for potential hardware failure models and accident scenarios must be developed. After that, the phenomena would need to be ranked either high, medium, or low depending on their importance relative to the 
evaluation criteria. During the knowledge-level step, the knowledge gathered about the identified safetyrelevant phenomena is carefully assessed. Finally, sufficient and in-depth documentation of the steps taken is necessary to share the results of the process with a knowledgeable reader. ${ }^{[11]}$

\subsection{Joint Licensing Approach}

A key part of the DOE mission is to encourage and conduct research and development for nuclear energy. DOE supports this mission through the use of research-oriented non-power reactors and nuclear reactor test facilities (under DOE control) made specifically for research and development ${ }^{[33]}$ Since these facilities are not for demonstration or commercialization, they do not need to be licensed by the NRC. Instead, the NRC can provide the DOE with technical assistance to ensure the safe construction and operation of DOE's proposed facility. In acting as an independent safety advisor, the NRC can provide DOE with "detailed briefings, guidance documents, and support them in developing important administrative and technical program elements of a regulatory program," ensuring that what they have created is safe and effective. ${ }^{[33]}$ In an attempt to expedite the licensing process for microreactors, more research related to the following question is needed:

\section{If construction and operation of a non-power facility has been heavily monitored and guided by the NRC, and contractors wish to convert the facility from non- power to power, is the facility required to start the NRC licensing process from the very beginning?}

If the answer is no, microreactors may benefit from improved timeliness of licensing activities by first going through the DOE process to allow early demonstration on a DOE site, then finish with the NRC process, providing an advantage for both applicants and NRC staff. ${ }^{[34]}$ Although non-power facilities are not concerned with major NRC licensing concepts like comparison studies and market analysis, they do have general alignment on safety through required safety evaluation reports that are reviewed by NRC personnel. A proposed flowchart for this joint approach is provided in Figure 4. Just as the two organizations have done in the past regarding the Gas Centrifuge Lead Cascade Facilities at the Portsmouth Gaseous Diffusion Plant site, the DOE and NRC should consider creating a memorandum of understanding to enter into a written mutual understanding of the roles and responsibilities of each organization and to clarify the regulatory boundaries between the two to avoid dual regulation procedures. ${ }^{[35]}$ The key points of this proposed memorandum can be found in

\section{DOE Process $\quad$ NRC Process}

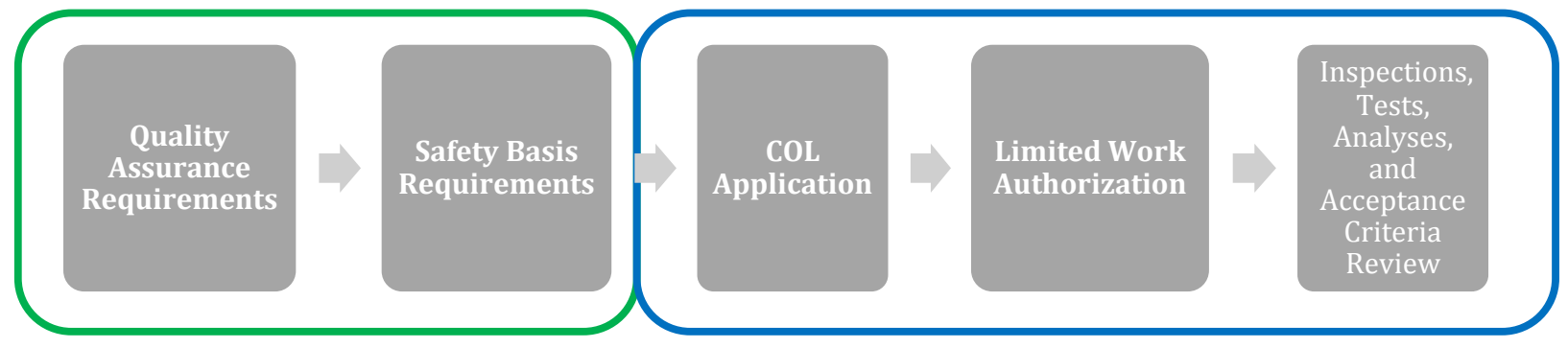

Table 5 .

Figure 4. Proposed DOE and NRC joint approach. 
Table 5. Key points of proposed memorandum of understanding.

\begin{tabular}{|c|c|c|c|}
\hline $\begin{array}{l}\text { Exchange of Information and Technical } \\
\text { Staff Support }\end{array}$ & Referrals & Coordination & $\begin{array}{l}\text { Resolution of } \\
\text { Disputes }\end{array}$ \\
\hline $\begin{array}{l}\text { DOE and NRC agree to: } \\
\text { - Make available to each other } \\
\text { information and technical support } \\
\text { concerning matters of common } \\
\text { interest } \\
\text { - Notify each other in a timely manner } \\
\text { of substantial proposed changes } \\
\text { - Share all observation, audit, } \\
\text { assessment, and inspection reports } \\
\text { - Inform each other of enforcement } \\
\text { actions. }\end{array}$ & $\begin{array}{l}\text { Each agency will be } \\
\text { responsible for } \\
\text { processing, under its } \\
\text { established program(s), } \\
\text { allegations - } \\
\text { declarations, statements } \\
\text { or assertions of } \\
\text { impropriety or } \\
\text { inadequacy whose } \\
\text { validity has not been } \\
\text { established - and } \\
\text { employee complaints or } \\
\text { concerns of regulatory } \\
\text { significance. }\end{array}$ & $\begin{array}{l}\text { DOE and NRC shall } \\
\text { consult with each } \\
\text { other before } \\
\text { disclosing } \\
\text { information related } \\
\text { to the MOU to } \\
\text { preclude } \\
\text { dissemination of } \\
\text { information which } \\
\text { may be exempt from } \\
\text { disclosure under the } \\
\text { Freedom of } \\
\text { Information Act. }\end{array}$ & $\begin{array}{l}\text { Resolution of } \\
\text { differences } \\
\text { between DOE } \\
\text { staff and NRC } \\
\text { staff will be the } \\
\text { initial } \\
\text { responsibility of } \\
\text { the DOE } \\
\text { Regulatory } \\
\text { Oversight } \\
\text { Manager, and the } \\
\text { chief of the } \\
\text { responsible branch } \\
\text { within the NRC. }\end{array}$ \\
\hline
\end{tabular}

\subsection{Department of Defense Strategy}

The Department of Defense has many years of experience with nuclear technology and applications. Their history with nuclear power begins in 1954, when the Navy launched the world's first nuclear powered submarine. From 1954 to 1979, the US Army Corps of Engineers ran a nuclear engineering program that used small reactors to provide power to remote installations that were too far from the power grid connection. The Army placed reactors in places like Fort Greeley, Alaska, Camp Century, Greenland, and McMurdo Sound, Antarctica, and conducted nuclear-effects testing with burst reactors at Aberdeen Proving Ground and White Sands Missile Range in New Mexico. ${ }^{[36]}$ The White Sands Missile Range, for example, "produces high-yield pulses of microsecond width, as well as long-term, steady state radiation, to closely simulate the neutron radiation environment produced by a fission weapon" and is the only fast-burst nuclear reactor that remains in the Army arsenal. ${ }^{[37][38]}$ Today, DoD bases need cyber-secure power and energy and remote bases need reliable energy that is not hindered by the high costs associated with fuel transport. Nearly half of these bases require electric power levels that are less than $10 \mathrm{MWe}$.

To address these issues, the National Defense Authorization Act of 2014 required that a Task Force examine the feasibility of small modular reactors for forward operating bases as a source of reliable power and to improve combat capability and deployed conditions for the DOD. ${ }^{[17][39]}$ The Task Force, which is in charge of energy demands and improving the energy effectiveness of our troops, came to the conclusion that energy usage on the battlefield is projected to significantly increase with time, and alternative energy sources like wind and solar are not likely to meet future energy demands for forward or remote operating bases. After reviewing both light water and advanced vSMR concepts, the Task Force decided that advanced vSMRs would be the best option to provide electricity, process heat, and water treatment, as well as to supply energy for energy-based weapons on forward-operating bases and remote operating bases. The suggested characteristics of advanced vSMRs for a military installation are summarized in Table 6. ${ }^{[17]}$ Two vSMRconcepts that were found to be technically mature are the MegaPower, being developed by Los Alamos National Laboratory, and Holos, developed by HolosGen. Unfortunately, due to strict licensing practices, regulatory approval can take 10 to 15 years. 
Table 6. DOD-suggested characteristics of advanced vSMRs.

\begin{tabular}{|l|l|}
\hline Time to install: 12-72 hours & $\begin{array}{l}\text { Twenty-five to forty tons; transportable by truck } \\
\text { or C-17 aircraft }\end{array}$ \\
\hline $\begin{array}{l}\text { Time for planned shutdown, cool down, } \\
\text { disconnect, and removal: 6 hours to 7 days }\end{array}$ & $\begin{array}{l}\text { Refueling should not be required more than } \\
\text { annually; fresh and used fuel should be } \\
\text { transportable by air, sea, and ground }\end{array}$ \\
\hline $\begin{array}{l}\text { Autonomous or semiautonomous operations with } \\
\text { minimal personnel required to monitor overall } \\
\text { health }\end{array}$ & $\begin{array}{l}\text { Capable of immediate shutdown and passive } \\
\text { cooling }\end{array}$ \\
\hline $\begin{array}{l}\text { Modular and scalable units capable of producing } \\
\text { 2-10 MWe and potentially useful heat }\end{array}$ & $\begin{array}{l}\text { No net increase in risk to public, military } \\
\text { personnel, or environment; no net increase in } \\
\text { consequences of adversary attack }\end{array}$ \\
\hline
\end{tabular}

According to the Army Reactor Council, Army Regulation (AR) 50-7 applies to all Army organizations that develop, test, support or operate nuclear reactors. Within the regulation is a procedure for implementing the Army Reactor Program, which was created to "ensure that Army reactors are operated in a safe, secure, and reliable manner from activation through decommissioning". ${ }^{[0]}$ Currently, the program policy consists of following NRC and National Council on Radiation Protection and Measurements regulations to the maximum extent possible. The Army standards are aimed at "maintaining radiation exposures to the public, the environment, and operating personnel to levels within regulatory limits and as low as reasonably achievable, minimizing the probability and consequences of a reactor accident or incident, and ensuring adequate security of reactors." [40] Additional governing regulations within the Army Reactor Program include AR 50-5, "Army Nuclear Surety"; AR 190-54, "Security of Nuclear Reactors and Special Nuclear Material"; and AR 385-10 "Army Safety Program." To construct and operate a reactor, applicants must apply for and obtain a construction permit, a load and test permit, an operating permit, a decommissioning permit, and a special permit. The construction permit gives licensees the permission to build or acquire the reactor. The load and test permit allows licensees to receive fuel, initialize core loading and characterize and test the reactor. The operating, decommissioning and special permits allow for routine use of the reactor, decommissioning of the reactor, and covering of other operations. ${ }^{[40]}$ The application details for each permit are provided in Figure 5. 


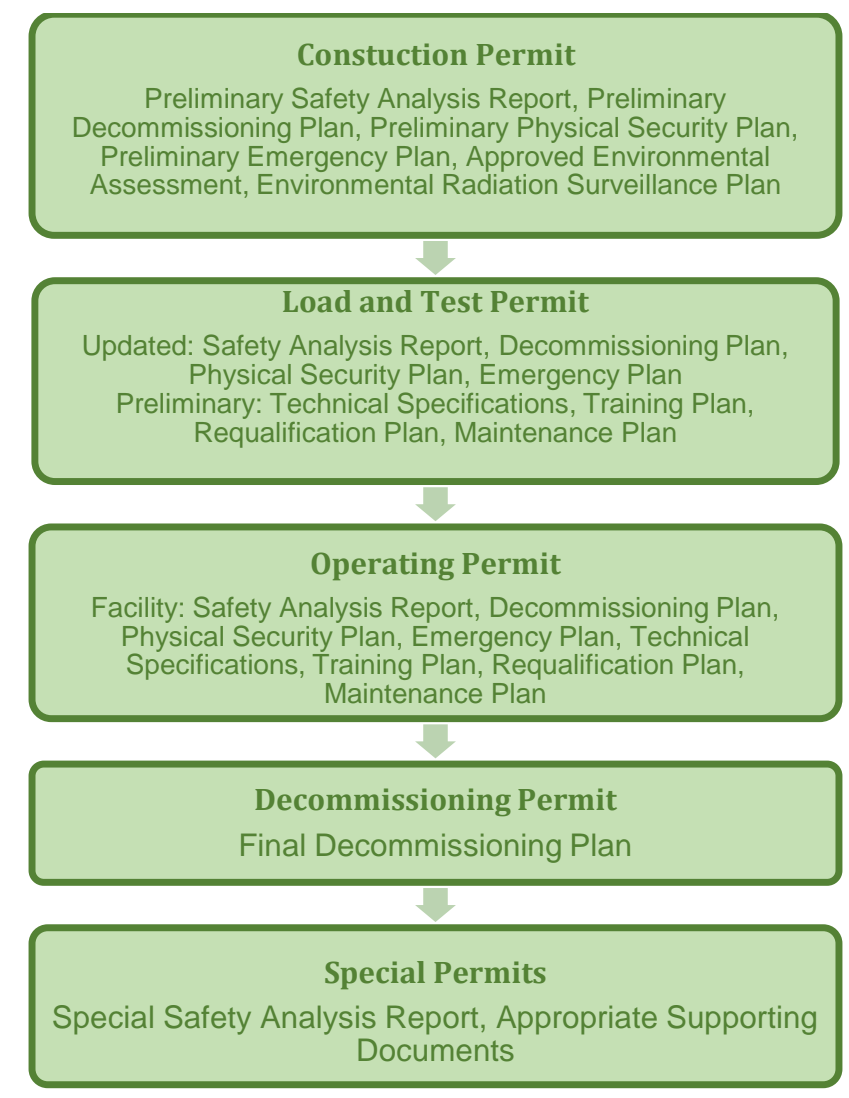

Figure 5. Details associated with Army reactor permit types.

Each application must include (1) the type of permit, (2) how the facility will be used, (3) the time period for which the permit is required, (4) documentation specific to each permit, including, but not limited to, a facility safety analysis report, decommissioning plan, physical security plan, emergency plan, technical specifications, training plan, requalification plan and maintenance plan. The safety of each reactor is monitored through Quality Assurance Program reviews, facility audits and reactor safety committees. Applications for reactor permits are sent through command channels to the Army Reactor Office (ARO). The ARO then issues the permits after the Director of Army Safety and the Deputy Chief of Staff (G-3/5/7) have approved the appropriate reactor study report. Each study report is created to evaluate "(1) potentially unsafe conditions, (2) modifications, alterations, or retrofits that affect reactor safety or security, (3) tests that affect reactor safety or security (4) significant changes or modifications in the operational concept that affect reactor safety or security and (5) any other condition that could affect reactor safety or security."[40]

\subsection{DoD Microreactor Licensing Recommendation}

\subsubsection{Section 91b of the Atomic Energy Act}

Rather than giving jurisdiction to the NRC for the regulation of microreactors, the DoD may invest in personnel with sufficient expertise to regulate their own reactors, as long as the reactor has unique military applications, like being incorporated into tactical power systems. ${ }^{[17]}$ The $\mathrm{DoD}$ is authorized to regulate mission-critical nuclear facilities under Section 91b of the Atomic Energy Act which states:

The President from time to time may direct the Commission (1) to deliver such quantities of special nuclear material or atomic weapons to the Department of Defense for such use as he deems necessary in the interest of national defense, or (2) to authorize the Department of Defense to manufacture, produce, or acquire 
any atomic weapon or utilization facility for military purposes: Provided, however, that such authorization shall not extend to the production of special nuclear material other than that incidental to the operation of such utilization facilities.

The Army Nuclear Program and the Naval Reactors Program are two successful examples of government organizations that were granted exception and were exempt from completing the NRC licensing process for their military reactors ${ }^{[36]}$ By incorporating microreactors into tactical power systems and hiring personnel with expertise (in supporting semi-autonomous operation of microreactors) to selfregulate, the DoD can expedite the permitting process by creating a less constraining but equally safe regulation process.

\section{TRANSPORTATION REGULATION}

The current fleet of LWRs use low-enriched uranium (LEU) fuel, which is fuel that has been enriched to less than 5\% uranium-235 (U-235). LEU is used to fuel all commercial nuclear applications. LEU is transported (on the front end) using Type A packaging. Type A packaging is used to transport small amounts of non-life-threatening radioactive material. The main goal of this packaging is to protect transportation workers and the general public from radiation exposure and to provide nuclear criticality safety under normal and severe conditions. ${ }^{[41]}$ For fresh fuel, the packaging may be made out of steel boxes placed within wooden boxes, or the fuel may be shipped in a cradle assembly that holds fuels firmly to a rigid beam called a "strongback." Once the fuel has been used within a reactor Type B packaging, which is used for material with the highest amount of radioactivity, is used to transport the material. ${ }^{[42]}$ To evaluate the transportation safety of used fuels, the NRC has conducted several risk assessments. These assessments have concluded that calculated per shipment risks have declined over the past 35 years due to advancements in tools available to determine cask responses and calculate consequences and risks. ${ }^{[43]}$

Advanced reactors, like microreactors, will require a different fuel form that contains higher enrichments, called high-assay low-enriched uranium (HALEU) fuel. ${ }^{[4]}$ HALEU is enriched to between $5 \%$ and $20 \%$, and is generated through either enriching LEU or by recovering and downblending highly enriched uranium. Currently, large scale shipments of HALEU have not been transported in a public arena because the U.S. Department of Transportation (DOT) has not yet approved commercially viable cylinders or packages for material that is enriched to greater than $5 \% \mathrm{U}-235 .{ }^{[44]}$ Once regulations have been put into place, Type B packaging is expected to be the best packaging for HALEU and fueled microreactors. Type $B$ packaging is very robust and can survive a wide range of potential accidents.

\subsection{Requirements for Transport}

\subsubsection{International Atomic Energy Agency Regulations}

The International Atomic Energy Agency (IAEA) is an organization with a mission of promoting safe, secure, and peaceful nuclear technologies. The safety standards that the IAEA uses to govern shipments of nuclear materials are the same basic standards used in the United States. ${ }^{[41]}$ Before a package of nuclear material can be transported for the first time, IAEA regulations require that the design specifications of the package comply with the following requirements: (1) If design pressure for the containment is larger than $35 \mathrm{kPa}$ (gauge), the containment system for each packaging must "conform to the approved design requirements relating to the capability of that system to maintain its integrity under that pressure," (2) for each packaging intended for Type B use or intended to contain fissile material, the effectiveness of its shielding, containment, heat transfer characteristics, and confinement systems must be within the limits specified for the approved design, and (3) the effectiveness of the criticality safety features for packaging containing fissile material is within the limits specified for the design, and the presence and distribution of neutron poisons are checked. 
For every shipment after the initial one, (1) all lifting attachments that do not meet specific requirements should be removed or rendered incapable of lifting the package, (2) each package containing fissile material must demonstrate its ability to close efficiently through inspection and/or tests, and (3) packages must be held until temperature and pressure approach specified equilibrium conditions. ${ }^{[55]}$

\subsubsection{NRC and DOT Regulations}

The applicable regulations and standards for transporting nuclear materials created by the NRC include 10 CFR 71, "Packaging and Transportation of Radioactive Material," 10 CFR 73, "Security," 10 CFR 74, "Material Control and Accountability," and 10 CFR 37, "Physical Protection in Transit."

\subsubsection{10 CFR 71}

"Packaging and Transportation of Radioactive Material" establishes the requirements for packaging, preparing for shipment, and transporting licensed material. All licensees must also comply with operating control, quality assurance, general provision, and package-approval standards requirements in order to gain NRC approval. This section, for example, details the structural, thermal, containment, and shielding requirements that state that the required dose rate must be less than $10 \mathrm{mrem} / \mathrm{hr}$ at distance of $2 \mathrm{~m}$, and criticality requirements that state that all contents must remain subcritical. ${ }^{[46]}$ Within this section are also NUREG 1609 and 1617. NUREG 1609 is a standard review plan for transportation packages for radioactive material that provides guidance for the review and approval of applications for packages used to transport radioactive material. Similarly, NUREG 1617 is a standard review plan for transportation packages, but for spent nuclear fuel, that provides guidance for the review and approval of applications for packages used to transport spent nuclear fuel. In addition, any licensee that transports licensed material outside the site of usage must comply with the applicable requirements of the DOT regulations in 49 CFR 107, 171-180, and 390-397. ${ }^{[47]}$ These regulations are summarized in Table 7.

Table 7. Title 49 DOT transportation regulations.

\begin{tabular}{|l|l|}
\hline \multicolumn{1}{|c|}{ Part } & \multicolumn{1}{c|}{ Title } \\
\hline 49 CFR 107 & Hazardous Materials Program Procedures \\
\hline 49 CFR 171 & General Information, Regulations, and Definitions \\
\hline 49 CFR 172 & $\begin{array}{l}\text { Hazardous Materials Table, Special Provisions, Hazardous Materials Communications, } \\
\text { Emergency Response Information, Training Requirements, and Security Plans }\end{array}$ \\
\hline 49 CFR 173 & Shippers-General Requirements for Shipments and Packagings \\
\hline 49 CFR 174 & Carriage by Rail \\
\hline 49 CFR 175 & Carriage by Aircraft \\
\hline 49 CFR 176 & Carriage by Vessel \\
\hline 49 CFR 177 & Carriage by Public Highway \\
\hline 49 CFR 178 & Specifications for Packagings \\
\hline 49 CFR 179 & Specifications for Tank Cars \\
\hline 49 CFR 180 & Continuing Qualification and Maintenance of Packagings \\
\hline 49 CFR 390 & Federal Motor Carrier Safety Regulations; General \\
\hline 49 CFR 391 & Qualifications of Drivers and Longer Combination Vehicle (LCV) Driver Instructors \\
\hline 49 CFR 392 & Driving of Commercial Motor Vehicles \\
\hline 49 CFR 393 & Parts and Accessories Necessary for Safe Operation \\
\hline 49 CFR 394 & Reserved \\
\hline 49 CFR 395 & Hours of Service of Drivers \\
\hline 49 CFR 396 & Inspection, Repair, and Maintenance \\
\hline
\end{tabular}




\begin{tabular}{|c|c|}
\hline Part & Title \\
\hline 49 CFR 397 & Transportation of Hazardous Materials; Driving and Parking Rules \\
\hline
\end{tabular}

\subsubsection{10 CFR $73 / 10$ CFR 74}

10 CFR 73 covers the "Physical Protection of Plants and Materials" from threats such as radiological and internal sabotage, cyber-attack, and land-vehicle bomb assaults. It describes all requirements for the establishment and maintenance of protection systems for plants and special nuclear material at fixed sites and in transit. 10 CFR 74 is the "Material Control and Accountability" section that contains the requirements for controlling, accounting for, and documenting the transfer of special nuclear material to and from fixed sites. This section includes a range of general to specific reporting requirements by which licensees possessing nuclear material must abide. ${ }^{[46][48]}$

\subsubsection{10 CFR 37, Subpart D}

The purpose of the "Physical Protection in Transit" section is to provide licensees with the requirements for the physical protection program of Category 2 radioactive material, to assure the security of these materials from theft or diversion. Any licensee that plans to conduct a transfer of Category 2 quantities of radioactive material to a licensee of the NRC or an agreement state must first verify with the NRC's license verification system that the transferee's license permits the receipt of the type, form, and quantity of material to be transferred. The licensee that transports the material must coordinate and document the shipment nolater-than arrival time, and the licensee who receives the material must immediately confirm receipt of the shipment with the originator. During transit of Category 2 materials by road, licensees must maintain constant control and/or surveillance over their shipment and must have the capability for immediate communication to summon response of assistance. This can be attained by established package tracking systems that require authorized signature prior to releasing the package for delivery or return. During transit by rail, similar to transit by road, licensees must have established package tracking systems that require authorized signature prior to release of the package and must maintain constant control and surveillance during transit. If the shipment has not arrived by the designated no-later-than arrival time, both licensees must immediately investigate the situation. The shipping licensee must also notify the NRC's Operations Center within four hours of determining that a shipment of Category 2 quantities of radioactive material is lost or missing. ${ }^{[48]}$

\subsection{Microreactor Transport Recommendation}

As previously mentioned, microreactors will require HALEU fuel, but the DOT has not yet approved commercially viable cylinders or packages for material that is enriched to greater than 5\% U-235. To ensure that HALEU fuel is available for future applications, the DOE should provide support in developing new shipping packages for safe transport, criticality-benchmark data needed to license HALEU facilities and transport packages, and financial and technical assistance to the Department of Transportation. The NRC must also aid transportation efforts by finalizing and developing guidance for implementing 10 CFR 73 and 10 CFR 74 specifically for Category 2 Special Nuclear Material. It has been estimated that in order to establish the commercial fuel-cycle infrastructure, a minimum of seven to nine years will be required. Once HALEU fuel licensing issues have been addressed, microreactors can be transported to forward operating bases by air to the theater and then by road to the base, as shown in the schematic provided in Figure $6 .{ }^{[17]}$ 


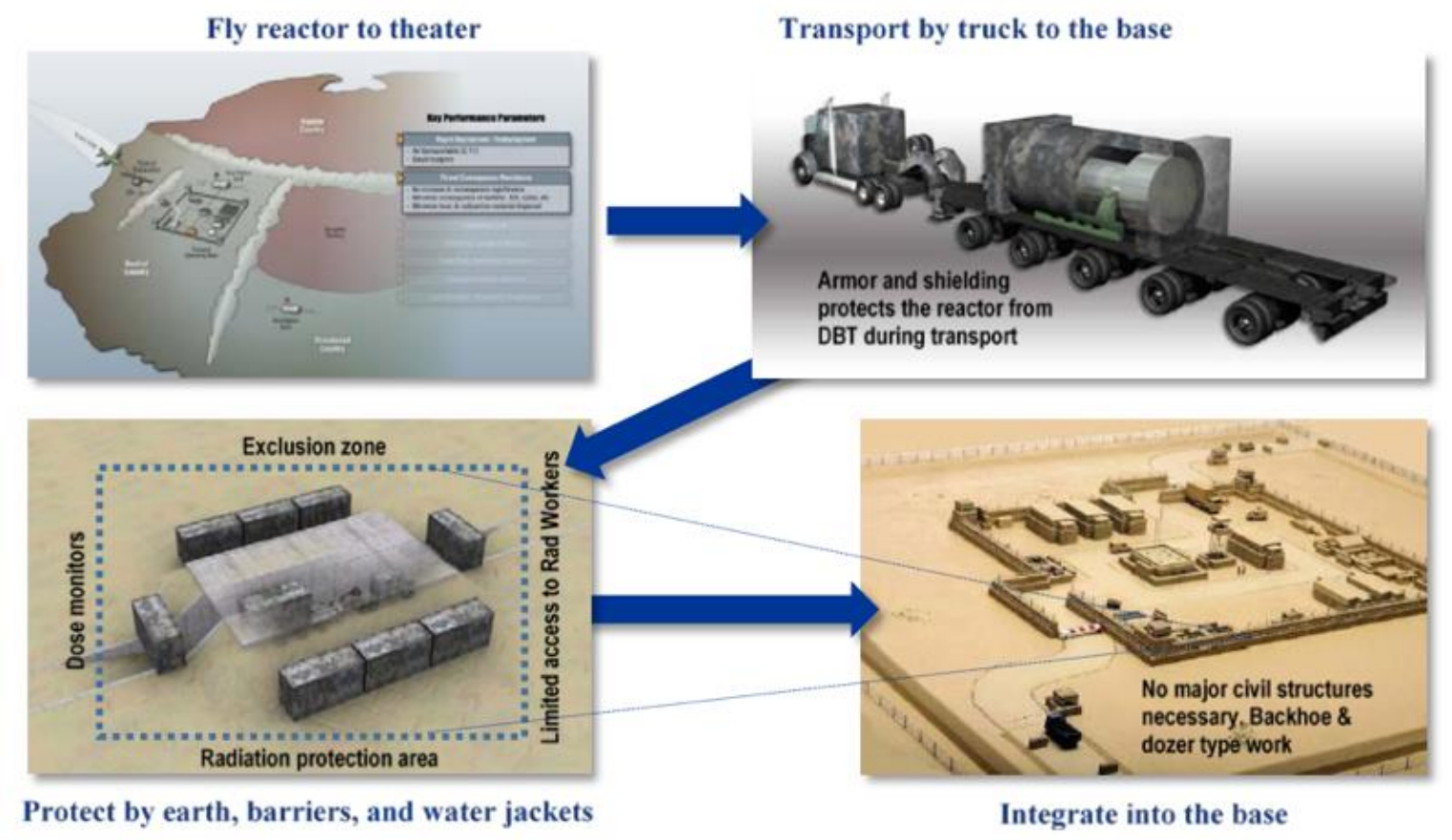

Figure 6. DOD task force vSMR transport to forward or remote operating bases.

\section{CONCLUSION}

With energy demand steadily increasing, microreactors have the potential to become an environmentally friendly, reliable, and decentralized energy source, used to provide sustainable and affordable energy and power to remote communities and industrial users. Their development, demonstration, and commercialization in a timely manner require the NRC, DOE, DoD, and DOT to work together to develop new rules specifically for this disruptive, game-changing technology and to revitalize the nation's capabilities in nuclear power. In doing so, they can ensure that organizations like Westinghouse, HolosGen, U-Battery, etc. can continue to positively influence our energy future with their innovative microreactor concepts and designs.

\section{REFERENCES}

[1] EIA, "How Many Nuclear Power Plants Are In The United States, and Where Are They Located? - FAQ - U.S. Energy Information Administration (EIA)," U.S Energy Information Administration. p. 1, 2017.

[2] W. C. Holton, "Power Surge: Renewed Interest In Nuclear Energy," Environ. Health Perspect., vol. 113, no. 11, pp. 742-749, 2005.

[3] M. S. Fertel, "Status and Outlook for Nuclear Energy in the United States," Energy Environ., vol. 22, no. 1-2, pp. 25-36, 2011.

[4] B. J. Mincher, "The Nuclear Renaissance: Producing Environmentally Sustainable Nuclear Power,” ACS Symp. Ser., vol. 1046, pp. 3-10, 2010.

[5] D. Buckthorpe, "Introduction to Generation IV Nuclear Reactors," Struct. Mater. Gener. IV Nucl. React., pp. 1-22, 2016.

[6] J. Vujić, R. M. Bergmann, R. Škoda, and M. Miletić, "Small Modular Reactors: Simpler, Safer, Cheaper?," Energy, vol. 45, no. 1, pp. 288-295, 2012. 
[7] B. Vegel and J. C. Quinn, "Economic Evaluation Of Small Modular Nuclear Reactors And The Complications Of Regulatory Fee Structures," Energy Policy, vol. 104, no. February, pp. 395403, 2017.

[8] L. Boldon, P. Sabharwall, C. Painter, and L. Liu, "An Overview Of Small Modular Reactors: Status Of Global Development, Potential Design Advantages, And Methods For Economic Assessment," Int. J. Energy, Environ. Econ., vol. 22, no. 5, 2014.

[9] Bragg-Sitton, Shannon. "Nuclear Technology Research and Development (NE-4): Special Purpose Applications.” Office of Nuclear Energy, 5 Feb. 2018. (PPT)

[10] Arafat, Y., and J. Van Wyk. "The Westinghouse EVinci Microreactor: Our Next Disruptive Technology.” Westinghouse, July 2018 (PPT)

[11] Werner, Hummel, Wright, and J. M. Biersdorf, "Special Purpose Nuclear Reactor (5 MW) for Reliable Power at Remote Sites Assessment Report Power at Remote Sites Assessment Report," no. April, 2017.

[12] U.S. Nuclear Regulatory Commission. "NRC — Independent Regulator of Nuclear Safety (NUREG/BR-0164, Revision 9).” U.S NRC, June 2012, www.nrc.gov/reading-rm/doccollections/nuregs/brochures/br0164/.

[13] “Nuclear Safety Regulatory Framework.” Department of Energy, 10 May 2010. (PPT)

[14] “About Us: Our Mission.” Department of Energy, 2017, www.energy.gov/about-us.

[15] R. J. Belles, R. E. Hale, and T. J. Harrison, “A Survey of Materials for Additive Manufacturing," no. June, 2018.

[16] “About Department of Defense," Us Department of Defense. 2016,https://dod.defense.gov/About/

[17] Defense Science Board, "Task Force on Energy Systems for Forward/Remote Operating Bases," no. September, pp. 1-35, 2016. http://www.dtic.mil/dtic/tr/fulltext/u2/1022571.pdf

[18] T. Wilde, S. Baker, and G. Sandquist, "Codes, Standards And Regulatory Topics For Nuclear Facilities,” Los Alamos National Laboratory, 2008.

[19] M. Holbrook, "MicroReactor Regulatory Considerations." (PPT)

[20] R. Mahan, K. Sutton, and D. Rosinski, "Theory to Practice: The Realities of New Reactor Licensing Application Docketing and Review," October, pp. 1-10, 2008.

[21] NRC, "Nuclear Power Plant Licensing Process," vol. Rev 2, 2004. https://www.nrc.gov/reading$\mathrm{rm} /$ doc-collections/fact-sheets/licensing-process-fs.html

[22] NRC, "New Reactors: Striving for Enhanced Safety.” 2011, https://www.nrc.gov/readingrm/doc-collections/nuregs/brochures/br0356/

[23] US Nuclear Regulatory Commission, “A Regulatory Review Roadmap For Non-Light Water Reactors," no. December, 2017.

[24] Nuclear Energy Research Initiative, "Risk Informed Assessment of Regulatory and Design Requirements for Future Nuclear Power Plants,” vol. 21902, 2003.

[25] K. Jamali, "Use Of Risk Measures In Design And Licensing Of Future Reactors," Reliab. Eng. Syst. Saf., vol. 95, no. 9, pp. 935-943, 2010.

[26] V. McCree, "Plans for Increasing Staff Capabilities to Use Risk Information in Decision Making Activities," 2012. 
[27] U.S. Nuclear Regulatory Commission, "Backgrounder: Research and Test Reactors," no. April, pp. 1-4, 1999.

[28] World Nuclear Association, "Nuclear Research Reactors.” June 2018, http://www.worldnuclear.org/information-library/non-power-nuclear-applications/radioisotopes-research/researchreactors.aspx

[29] U.S. Nuclear Regulatory Commission, "NUREG 1537: Guidelines for Preparing and Reviewing Applications for the Licensing of Non-Power Reactors," p. Part 1, 1996.

[30] M. R. Holbrook, J. C. Kinsey, and W. L. Moe, "Licensing Basis Event Selection Framework for Advanced Reactors," pp. 1-7, 2016.

[31] U.S. Government Publishing Office, "Part 830 - Nuclear Safety,” pp. 542-556, 2011.

[32] U.S. Department of Energy, "DOE Standard: Hazard Categorization and Accident Analysis Techniques for Compliance with DOE Order 5480.23, Nuclear Safety Analysis Reports," no. December 1992, 1997.

[33] T. Garvey, "Memorandum: NRC Licensing of Proposed DOE Nuclear Facilities," pp. 1-7, 2015.

[34] J. Mazza, "Licensing Framework for Advanced Reactors DOE-NRC Joint Initiative Workshop on Molten Salt Reactor Technologies October 2015 Need for a Licensing Framework for Advanced Reactors," no. October, 2015.

[35] D. Jackson, "NRC: Memorandum of Understanding Between the Department of Energy and the Nuclear Regulatory Commission.".

[36] M. King, L. Huntzinger, and T. Nguyen, "Feasibility of Nuclear Power on Military Installations," no. September, 2011.

[37] Army Nuclear Surety Program, "Position Description for White Sands Missile Range, NM," Office, vol. 8, pp. 2-3, 2004.

[38] White Sands Missile Range, "Survivability Vulnerability." http://www.wsmr.army.mil/testcenter/org/Pages/SurvivabilityVulnerability.aspx

[39] K. Ananth, "Portable Special Purpose Nuclear Reactor (2 MW) for Remote Operating Bases and Microgrids," pp. 1-27, 2017.

[40] Department of the Army, "Army Regulation 50-7." 1996, https://www.nrc.gov/docs/ML1117/ML111730149.pdf

[41] W. Brobst, "Transportation of Nuclear Fuel and Waste," Nucl. Technol., vol. 24, no. 3, pp. 343355, 1974.

[42] U.S. Department of Energy, "Radioactive Material Shipping Packages,” pp. 1-12. https://training.fema.gov/emiweb/is/is302/ss_mod05_sg.pdf

[43] U.S. Department of Energy, "NUREG-2125 Spent Fuel Transportation Risk Assessment," p. 517 https://www.nrc.gov/docs/ML1212/ML12125A218.pdf.

[44] M. Tschiltz, "Addressing the Challenges with Establishing the Infrastructure for the Front-End of the Fuel Cycle for Advanced Reactors," no. January, 2018.

[45] G. Gazzette et al., "Regulations for the Safe Transport of Radioactive Materials," Am. J. Public Heal. Nations Heal., vol. 58, no. 5, pp. 989-990, 2010.

[46] U.S. Nuclear Regulatory Commission, "10 CFR 71 Purpose and Scope.” 2004, https://www.nrc.gov/reading-rm/doc-collections/cfr/part071/part071-0000.html 
[47] Code of Federal Regulations, “Title 49 Transportation Parts 100-177," 2014, Code of Federal Regulations, "Title 49 Transportation Parts 100-177," 2014.

[48] U.S. Nuclear Regulatory Commission, "Nuclear Materials Transportation Regulations, Guidance, Communications.”2017, https://www.nrc.gov/materials/transportation/regs-guides-comm.html . 